\title{
Students' Intentions and Students' Attainments at the On-campus House: A desk study
}

\author{
Nurul ‘Ulyani Mohd Najib, Nor’Aini Yusof, Amin Akhavan Tabassi \\ School of Housing, Building \& Planning, \\ Universiti Sains Malaysia, Penang, Malaysia
}

numn11_hbp088@student.usm.my, ynoraini@usm.my, akhavan@usm.my

\begin{abstract}
There is large call in Malaysia to study on how tertiary students perceived the performance of service quality of student housing; and to understand on how they translated their perceptions into behavioural intentions and personal attainments. The rationale for this paper is to explain the elements which constitute behavioural intentions and personal attainments; which is based on conventional reviews of plentiful volume of published journals from 1985 until 2014 in the area of student housing research. The results of the review clarified that behavioural intentions consist of favourable and unfavourable intentions; while personal attainments comprise of intellectual and self-development gains.

Keywords: Service quality performance; student housing; behavioural intentions; personal attainments

eISSN 2514-7528 @ 2018. The Authors. Published for AMER ABRA cE-Bs by e-International Publishing House, Ltd., UK. This is an open-access article under the CC BY-NC-ND license (http://creativecommons.org/licenses/bync-nd/4.0/). Peer-review under responsibility of AMER (Association of Malaysian Environment-Behaviour Researchers), ABRA (Association of Behavioural Researchers on Asians) and cE-Bs (Centre for EnvironmentBehaviour Studies), Faculty of Architecture, Planning \& Surveying, Universiti Teknologi MARA, Malaysia.

DOI: https://doi.org/10.21834/jabs.v3i10.316
\end{abstract}




\subsection{Introduction}

So far, Malaysia has successfully gaining a global recognition and currently ranked at $11^{\text {th }}$ worldwide by United Nations Educational, Scientific, and Cultural Organization (UNESCO) for her appeal to students as a preferred destination for tertiary and higher education (MOHE Promotional Information (Overview), 2014). To boost the current rank and to make Malaysian universities as always a comfortable and perfect choice of place to pursuing the study, advanced infrastructures along with sufficient facilities need to be provided and seriously taken into account (Down, 2009; Muslim et al., 2012a; Oluwunmi et al., 2012). One of the major concerns on sophisticated university's infrastructures and facilities is the provision of on-campus student housing with the superior housing facilities and good housing services. Having an excellent educational environment on-campus, not only to engender as much as possible tiptop students, it is also a welcoming approach for Malaysia to be able to attract even more local students to pursue their education in the country along with international individuals who are planning to study abroad (Mansur, 2011; Khaled, 2012).

As for the research gaps, most studies on students' residential satisfaction focused on the factors affecting residential satisfaction, students' adaptability style of living in student housing, and assessment of student housing quality (e.g. Amole, 2012; Najib et al., 2012; Abdullah et al., 2013). Therefore, little can be learned from those studies with regard to the relationship between perceiving service quality performance of on-campus student housing with students' behavioural intentions (BIs) and students' personal attainments (PAs). In Malaysia, there is also limited research in understanding how students perceived the performance of service quality of student housing (e.g. Bashir et al., 2012; Zainuddin et al., 2014). Bashir et al. (2012) revealed that students perceived service quality in Malaysian student housing as slightly good quality and Zainuddin et al. (2014) found that students almost dissatisfied with the quality of their student accommodation. Nevertheless, studies on how the students translated their perceive service quality perceptions into Bls and PAs are rare and being neglected. Besides, the current measurement of students' Bls and students' PAs in Malaysia is flawed plus the study on this topic from the view of facilities management is limited. Therefore, this study being the pioneer on the study of such relationship between perceiving service quality performance of on-campus student housing with students' Bls and students' PAs, has significant value in enriching the body of knowledge.

The main research question of the study is "What are the elements that exist to constitute students' Bls and students' PAs at the universities in Malaysia?". The principal objective is to explore the way in which students' Bls and students' PAs in their universities can potentially be assessed in a more appropriate and even better approach. The second objective is to develop a clear framework of the measurement elements that should be used in evaluating students' Bls and students' PAs for future research reference. Prior to discussing the earlier model on the aforementioned topic, the existing works of Parasuraman et al. (1985), Cronin and Taylor (1992), Zeithaml et al. (1996), Cronin et al. (2000), Tam (2002), Rinn (2004), Olorunniwo et al. (2006), Radder and Han (2009), Bashir et al. (2012), and Mohammad et al. (2012) in the field of service industry and post-occupancy evaluation have been critically reviewed. 


\subsection{Service Quality Performance of On-Campus Student Housing}

Oluwunmi et al. (2012) reckoned that appraising service quality performance is a kind of internal evaluation or monitoring system in order to build a feedback mechanism to present the state of facilities with services and their current performance. Furthermore, service quality performance appraisal in student housing is also a mean of maintaining the quality service and proposing the efficient design of service delivery process in supervising the good student housing (Mohammad et al., 2012). Theoretically proven that the most reliable ways to assess the service quality performance of student housing are through the uses of either Service Quality (SERVQUAL) model or Service Performance (SERVPERF) model which had been proposed by Parasuraman et al. (1985) and Cronin and Taylor (1992) respectively.

In dealing with the high demanding students nowadays, Chan et al. (2011) alluded that students are expecting for a continuous improvement being made to their student housing accordingly to their customization and personalization. This is because having a supportive, modern, and cosy living condition in on-campus student housing is believed can create a healthy or educated environment for study purpose and induce social solidarity in a big and mix community. As Bean and Bradley (1986), Cleave (1996), Rinn (2004), and Nugent (2012) contended that quality student housing is very vital which will significantly stimulate student's personal development, enhance academic achievements, and refine social dealings of the students.

Today, the students desire for a luxurious and high standard homelike living with everything in en-suite style and private rooms (Chan et al., 2011). Thus, Fish (2010) insisted that to build an exclusive on-campus student housing, the right understanding of students different wants and needs for their house is very attentive. By creating a living-learning environment that promoted collaboration, nourished cohesion, and friendly community in the campus area, it can develop social skills to help students become the mature adults and prepare them for the future (Cleave, 1996; Fish, 2010). Likewise, Chan et al. (2011), Nugent (2012), and Muslim et al. (2013) reckoned that the focus of building on-campus student housing must be deliberately thoughtful to stimulate satisfactory living condition and positively affect people-environment congruity to grant for the academic success, students' self-development, as well as perfect Bls.

By using the SERVQUAL/SERVPERF model to evaluate the student housing condition in Africa and Malaysia, basically, the common factors to affect Bls and PAs are related to the quality performance of physical, social, and management aspect of the provided on-campus student housing (Radder \& Han, 2009; Mohammad et al., 2012; Bashir et al., 2012). Amole (2005), Hassanain (2008), and Radder and Han (2009) opined that the presence of repute and efficient student housing system in the campus area may help students to attain the intellectual competence along with forming personal development and character which should lead to a fulfilling of students' on-campus living experience. Chan et al. (2011) and Mohammad et al. (2012), in other way, proclaimed that perceiving good service quality in student housing should intensify the students' loyalty with their current housing for the next semesters. In a nutshell, factors to influence the students' Bls and students' PAs at the university are best be determined by the service quality of the provided on-campus student 
housing. Hence, what are actually those students' Bls and students' PAs? The next sections discourse on that Bls and PAs in greater details.

\subsection{Exploration of Students' Behavioural Intentions And Students' Personal Attainments}

\subsection{Students' Behavioural Intentions}

From the Ajzen \& Fishbein's theory of reasoned action, Bls are the salient information or immediate antecedent of someone for performing a certain behaviour which is under full volitional control (Madden et al., 1992). In housing studies, Carpenter and Oloufa (1995) posited that Bls are the residents' response to the environment and the facility on how well their building's needs and goals have been supported. Thus, Zeithaml et al. (1996) and Olorunniwo et al. (2006) determined that Bls can be categorized into two types as favourable Bls which consist of loyalty thought and unfavourable Bls which lie about betrayal thought.

\subsection{Favourable Behavioural Intentions}

Favourable Bls can be described as good behavioural beliefs about the likelihood to show positive behaviours (e.g., positive words-of-mouth, recommendation, retention, and repurchase) as well as to strengthen the relationship between someone and the service provider (Madden et al., 1992; Zeithaml et al., 1996). Usually, loyalty or re-patronization of a product or services comes from the customers or residents who are satisfied with their house or perceived service quality at a maximum level (Mohammad et al., 2012). Specifically in student housing research, Chan et al. (2011) and Muslim et al. (2012b) emphasized that if the on-campus student housing is luxury, attractive, and has all the needed necessities and amenities, the students are prone to stay longer and be loyal to their house.

\subsection{Unfavourable Behavioural Intentions}

Unfavourable Bls can be defined as bad behavioural beliefs about the likelihood to perform negative behaviours (e.g., negative words-of-mouth, complaint, and migration) as well as weaken the relationship between someone and the service provider (Madden et al., 1992; Zeithaml et al., 1996). Olorunniwo et al. (2006) clarified that when the customers perceived a low service quality in their dealings, they tend to execute unfavourable Bls. Moreover, customers who encountered service problems, perceived inferior service or poor business operation are also more likely to leave, spend less or dislike the company (Zeithaml et al., 1996). Similarly to the housing study, residents who received imperfect neighbourhood in their residential area are usually forced to migrate to a better place (Sam et al., 2012).

\section{3,4 Students' Personal Attainments}

Rinn (2004) remarked that students' PAs are measuring the competency, integrity, selfreliantly, emotions management, identity establishment, and personal affairs development of the students. As such, Tam (2002: p.228) acknowledged that "Any institution is therefore 
considered "excellent" if it can deploy its resources wisely and effectively to facilitate the intellectual and personal development of its students". Thus, Rinn (2004) and Fish (2010) alleged that intellectual gains usually can be achieved in the classroom, but self-development gains are emerged and evolved by mixing and engaging with others while staying and living in the on-campus student housing.

\subsection{Intellectual Gains}

Intellectual gains are personal growth which is more private and individually-directed attainment (Tam, 2002; Billups, 2008). Normally, students intellectual gains being identified as an academically outcome and certainly being signified with Cumulative Grade Point Average (CGPA) (Becker et al., 2009). Thus, Rinn (2004) alleged that with a surrounding of higher educational aspirations, students who lived in the on-campus student housing are more persistence, determine to graduate, and to attain their degree. This is because, in this kind of situation, students are getting a higher chance to be more focused on their study and possibly to mingle around with the success-oriented peers.

\subsection{Self-Development Gains}

Self-development gains are social growth which is the involvement in planned group activities and public interactions (Tam, 2002; Rinn, 2004; Billups, 2008). Most of the students who choose to reside in the on-campus student housing are more often to engage well with other students from diverse background in their residential community whereby this nature upholds and teaches the esprit de corps, leadership, and independence life skills (Amole, 2007; Fish, 2010; Muslim et al., 2012b). For example, Bean and Bradley (1986) professed that the trend of freshman orientation as one of the campus housing programs which create peopleenvironment cohesion usually should indirectly increase students' interaction ability and being more socially adjusted. Nugent (2012) postulated that this encouraging milieu is also vitally helping to develop students as impressive individuals in the future.

\subsection{Methods of Review}

A desk study of this current research employed the methodology of archival research technique and content analyses research technique. Archival research technique deals with information exploration process while content analyses research technique addresses the research objectives (Sam et al., 2012; Muslim et al., 2012b). Henceforth, literature search was done exhaustively using that archival research technique, with hundreds of published articles related to the aforesaid research topic were searched and scanned in Elsevier, EBSCOHost, Emerald, SAGE Premier, ScienceDirect, and SpringerLINK databases. Either index journals or non-index journals, both which had been published for the last 29 years from 1985 until 2014 were downloaded and thoroughly been reviewed.

Principally, a comprehensive and conventional reviews discourses on the service quality performance of student housing, SERVQUAL, SERVPERF, Bls of students after experiencing living in on-campus student housing, and students' PAs at the universities. 
Through the content analyses research technique, the elimination of duplicate titles and those are apparently not related to the literature review was done. Only suitable and allied concepts, main findings, and research method covered in each article were extracted. All the remaining useful and relevant journal articles were traced from the Procedia - Social and Behavioral Sciences, Journal of College and University Student Housing, College Student Journal, Quality Assurance in Education, Journal of Facilities Management, Facilities, Journal of Architectural Engineering, Environment and Behaviour, Journal of Marketing, Journal of Services Marketing, and others.

\subsection{Results}

\section{Propositions to Conceptualization Of Behavioural Intentions And Personal Attainments}

The main objective of this paper is to develop a clear framework of the measurement elements that should be used in evaluating students' BIs and students' PAs at the university. The review results clarified that students' Bls consist of favourable Bls and unfavourable Bls; whereas students' PAs are theorized about intellectual gains and self-development gains. Table 1 shows the variables used to measure the students' Bls; consist of words-of-mouth, recommendation, encouragement, duration of stay, re-apply, and contribution.

Table 1: Variables to measure students' Bls

\begin{tabular}{ll}
\hline Favourable Bls & Unfavourable Bls \\
\hline Good words-of-mouth about the house & Bad words-of-mouth about the house \\
Recommend the house to others & Complaint about the house to others \\
Encourage friends to stay together & Discourage friends to stay together \\
Stay longer in the same room/house & Stay shorter in the same room/house \\
Re-apply the house for the next semester & Move to other house for the next semester \\
Contribute money as an alumnus & Not contribute money as an alumnus \\
\hline
\end{tabular}

(Source: Zeithaml et al. (1996), Cronin (2000), Olorunniwo et al. (2006))

Whereas, Table 2 displays the variables used to evaluate students' PAs; comprise of grades, problem-solving skills, thinking, ideas, self-learning, and acceptance as elements for intellectual gains. For self-development gains, the elements include variables such as independence, values, self-abilities, understanding, responsibility, and teamwork.

Table 2: Variables to measure students' PAs

\begin{tabular}{|c|c|}
\hline Intellectual Gains (Ability to ......) & Self-development Gains (Ability to ......) \\
\hline Get higher exam grades & Develop independence and self-reliance \\
\hline Develop the analytical and problem-solving skills & Develop values and ethical standards \\
\hline Think critically & Understand self-abilities, interests, and personality \\
\hline $\begin{array}{l}\text { Put ideas together, see relations, similarities, and } \\
\text { differences }\end{array}$ & Understand and get along with other people \\
\hline $\begin{array}{l}\text { Learn on my own, pursue ideas, and find information } \\
\text { Accept diverse views and opinions }\end{array}$ & $\begin{array}{l}\text { Gain a strong sense of social responsibility } \\
\text { Function as a team member }\end{array}$ \\
\hline
\end{tabular}

(Source: Tam (2002), Billups (2008)) 


\subsection{Discussions}

The present study is motivated by the need for higher service quality performance of oncampus student housing in Malaysia and the debate on which measurement elements that should be used to evaluate students' Bls and students' PAs. The review of past studies on the service quality performance of on-campus student housing, students' BIs, and students' PAs, showed that previous studies have established some directions to propose a framework on how to measure the students' Bls and students' PAs for this study in a better way. Referring to Table 1 and Table 2, it was found that to evaluate students' favourable and unfavourable Bls towards their on-campus student housing, the variables comprise of positive and negative elements. Whereas, to assess students' PAs in the universities, the variables entail of elements about intellectual and self-development gains. Above all, former studies have clearly proven that perceiving service quality performance of on-campus student housing can significantly influence students' BIs and students' PAs in the universities.

\subsection{Conclusion}

In ensuring the students can feel a comfortable and pleasant campus and student lifestyle in their on-campus student housing, thus, the university governance besides the government especially policy officials are accountable to provide high quality facilities and services to these people (Brackertz \& Kenley, 2002; Brackertz, 2006; Jiboye, 2011). Hence, regular assessment of the service quality performance of the on-campus student housing is expected and very important because it can affect individual's quality of life. The review results add to our understanding on the influence of quality services of the on-campus student housing onto students' BIs and students' PAs. For instance, previous studies have proven that high quality of student housing will influence positive students' Bls plus excellent students' PAs. The framework of this study submitted that service quality performance of on-campus student housing as the independent variable while students' Bls and students' PAs as dependent variables. Finally, this review will add to the body of knowledge in the area of facilities management specifically in the student housing studies. The conceptualization of students' Bls and students' PAs which has brought forward in this study is valuable for future research reference and imitation.

\section{Acknowledgement}

The researchers wish to express their sincere gratitude to the Universiti Sains Malaysia (IPS Fund, Account Number: 308/AIPS/415401) and Ministry of Higher Education Malaysia MyBrain15 (MyPhD) Scholarship for the financial support of this study. This paper was presented in the Asian Conference on Environment-Behaviour Studies, which was held in Seoul, August, 25-27, 2014. 


\section{References}

Abdullah, I. C., Muslim, M. H., \& Karim, H. A. (2013). An Assessment on Variable Reliability in Investigating Students' Living Satisfaction in Private Housing Environment. Procedia - Social and Behavioral Sciences, 101, 354-367.

Amole, D. (2005). Coping Strategies for Living in Student Residential Facilities in Nigeria. Environment and Behaviour, 37, 201-219.

Amole, D. (2007). A Study of the Quality of Student Residential Facilities in Nigeria. Planning for Higher Education, 35(4), 40-50.

Amole, D. (2012). Gender Differences in User Response to Students Housing. Procedia - Social and Behavioral Sciences, 38, 89-99.

Bashir, S., Sarki, I. H., \& Samidi, J. (2012). Students' Perception on the Service Quality of Malaysian Universities' Hostel Accommodation. International Journal of Business and Social Science, 3(15), 213-222.

Bean, J. P., \& Bradley, R. K. (1986). Untangling the Satisfaction-Performance Relationship for College Students. The Journal of Higher Education, 57(4), 393-412.

Becker, C., Cooper, N., Atkins, K., \& Martin, S. (2009). What Helps Students Thrive? An Investigation of Student Engagement and Performance. Recreational Sports Journal, 33, 139-149.

Billups, F. D. (2008). Measuring College Student Satisfaction: A Multi-Year Study of the Factors Leading to Persistence. Northeastern Educational Research Association (NERA) Annual Conference, Mansfield, Connecticut, $1-17$.

Brackertz, N. (2006). Relating physical and service performance in local government community facilities. Facilities, 24(7/8), 280-291.

Brackertz, N., \& Kenley, R. (2002). A service delivery approach to measuring facility performance in local government. Facilities, 20(3/4), 127-135.

Carpenter, C. L., \& Oloufa, A. A. (1995). Postoccupancy Evaluation of Buildings and Development of Facility Performance Criteria. Journal of Architectural Engineering, 1(2), 77-81.

Chan, J., Dubois, S., Fahey, R., \& Josephs, S. (2011). Evaluating Student Housing in London. MA: BSc Dissertation, Worcester Polytechnic Institute, Worcester.

Cleave, S. L. (1996). Residence Retention: Reasons Student Choose to Return or Not to Return. College Student Journal, 30, 187-199.

Cronin, J. J., \& Taylor, S. A. (1992). Measuring Service Quality: A Reexamination and Extension. Journal of Marketing, 56(3), 55-68.

Cronin, J. J., Brady, M. K., \& Hult, G. T. (2000). Assessing the Effects of Quality, Value, and Customer Satisfaction on Consumer Behavioural Intentions in Service Environments. Journal of Retailing, 76(2), 193-218.

Down, D. (2009, September 6). Malaysia: Future hub of international education? Retrieved November 22, 2012, from University World News, The Global Window on Higher Education: http://www.universityworldnews.com/article.php?story=20090903203756838 
Fish, C. T. (2010). The Case for Traditional On-Campus Housing. School Construction News - Design + Construction + Operations, 16(2), 12-13.

Hassanain, M. A. (2008). On the performance evaluation of sustainable student housing facilities. Journal of Facilities Management, 6(3), 212-225.

Jiboye, A. D. (2011). Evaluating Public Housing Performance: Providing a Basis for Residential Quality Improvement in Nigeria. Middle-East Journal of Scientific Research, 9(2), 225-232.

Khaled, M. (2012). 35 IPT diiktiraf cemerlang. (R. M. Ruzki, Interviewer).

Madden, T. J., Ellen, P. S., \& Ajzen, I. (1992). A Comparison of the Theory of Planned Behavior and the Theory of Reasoned Action. Personality and Social Psychology Bulletin, 18(1), 3-9.

Mansur, K. (2011). Mapum utamakan kualiti kolej kediaman universiti. (I. A. JS, Interviewer) Kota Kinabalu: New Sabah Times.

Mohammad, M. I., Gambo, Y. L., \& Omirin, M. M. (2012). Assessing Facilities Management Service in Postgraduate Hostel Using Servqual Technique. Journal of Emerging Trends in Economics and Management Sciences, 3(5), 485490.

Muslim, M. H., Karim, H. A., \& Abdullah, I. C. (2012a). Challenges of Off-Campus Living Environment for NonResident Students' Well-Being in UiTM Shah Alam. Procedia - Social and Behavioral Sciences, 50, 875-883.

Muslim, M. H., Karim, H. A., \& Abdullah, I. c. (2012b). Satisfaction of Students' Living Environment between OnCampus and Off-Campus Settings: A conceptual overview. Procedia - Social and Behavioral Sciences, 68, 601614.

Muslim, M. H., Karim, H. A., Abdullah, I. C., \& Ahmad, P. (2013). Students' Perception of Residential Satisfaction in the Level of Off-Campus Environment. Procedia - Social and Behavioral Sciences, 105, 684-696.

Najib, N. U., Yusof, N., \& Sani, N. M. (2012). The Effects of Students' Socio-Physical Backgrounds onto Satisfaction with Student Housing Facilities. Procedia-Social and Behavioral Sciences, 62, 64-74.

Nugent, J. (2012). Solving the Puzzle of Residential Life. Retrieved December 12, 2012, from College Planning \& Management: http://peterli.com/cpm/archive.php?article_id=3378

Olorunniwo, F., Hsu, M. K., \& Udo, G. J. (2006). Service quality, customer satisfaction, and behavioral intentions in the service factory. Journal of Services Marketing, 20(1), 59-72.

Oluwunmi, A. O., Akinjare, O. A., \& Oluwatoyin, I.-M. O. (2012). User's Satisfaction with Residential Facilities in Nigerian Private Universities: A Study of Covenant University. Transnational Journal of Science and Technology, 2(11), 89-112.

Parasuraman, A., Zeithaml, V. A., \& Berry, L. L. (1985). A Conceptual Model of Service Quality and Its Implications for Future Research. Journal of Marketing, 49, 41-50.

MOHE Promotional Information (Overview). (2014, February 4). Retrieved from The Official Website of Department of Higher Education: http://jpt.mohe.gov.my/eng/menupemasaran.php

Radder, L., \& Han, X. (2009). Service Quality of On-Campus Student Housing: A South African Experience. The International Business \& Economics Reserach Journal, 8(11), 107-119. 
Mohd Najib, N.U., et.al. / Journal of ASIAN Behavioural Studies (jABs), 3(10) Sep / Oct 2018 (p.170-179)

Rinn, A. N. (2004). Academic and Social Effects of Living in Honors Residence Halls. Journal of the National Collegiate Honors Council, 66-79.

Sam, M., Zain, M. F., \& Saadatian, O. (2012). Residential satisfaction and construction. Scientific Research and Essays, 7(15), 1556-1563.

Tam, M. (2002). Measuring the effect of higher education on university students. Quality Assurance in Education, 10(4), 223-228.

Zainuddin, S., Kahmis, M., Muhamad, A., \& Mamat, N. (2014). Perception and Expectation of Students Towards the Service Quality: Perspective in Malaysian Research University. Malaysian Online Journal of Educational Management (MOJEM), 2(2), 73-91.

Zeithaml, V. A., Berry, L. L., \& Parasuraman, A. (1996). The Behavioral Consequences of Service Quality. Journal of Marketing, 60, 31-46. 